\title{
THE EFFECTIVENESS OF CHLORINE TABLETS TO REDUCING COLIFORM IN WASTEWATER TREATMENT PLANT
}

\author{
Sri Arofah Mulyati ${ }^{1 *}$, Maidaswar $^{1)}$, Srikandi $^{2)}$, Mia Azizah $^{2)}$, Neneng Atikah ${ }^{1)}$ \\ ${ }^{1)}$ Balai Besar Pengujian Mutu dan Sertifikasi Obat Hewan, Gunungsindur, Jl. Raya Pembangunan, \\ Gunungsindur, Bogor 16340, Indonesia \\ ${ }^{2)}$ Program Studi Biologi, FMIPA, Universitas Nusa Bangsa, Jl. KH. Sholeh Iskandar KM 4, \\ Cimanggu, Tanah Sareal, Bogor 16166, Indonesia
}

\begin{abstract}
ARTICLE INFO
Article history:

Received 22 Sep 2021,

Revised 12 Jan 2022 ,

Accepted 16 Jan 2022

Available online 24 Jan 2022

Keywords:
$\checkmark$ Coliform
$\checkmark$ Chlorine
$\checkmark$ Wastewater
$\checkmark$ WWTP
$\checkmark$ Quality standard

ABSTRACT

Wastewater originating from experimental animal cages that are not treated properly can be a source of pollution because it contains organic, inorganic materials and even pathogenic microorganisms. Disinfection using chlorine is the last step in the wastewater treatment process to reduce microorganisms. This study aimed to determine the effectiveness of chlorine tablets in reducing the content of Coliform from experimental animal cage wastewater at the Wastewater Treatment Plant (WWTP) to meet the Total Coliform quality standard in the Regulation of the Minister of Environment and Forestry No. 68 of 2016 concerning domestic wastewater quality standards. The research was conducted using laboratory experiments pre and post-test. Wastewater samples were taken from 2 points, namely, the point inlet (before treatment) and outlet (after chlorination), the MPN test Coliform (SNI 2897 2008) were repeated twice, and the measured pH and temperature to analyze environmental factors. The results showed that $200 \mathrm{~g}$ of chlorine tablets could effectively reduce Coliform up to $98.55 \%$ and meet the quality standards used as a reference.
\end{abstract}

*corresponding author:

chiarofah@gmail.com

Phone: +6285222308080

https://doi.org/10.31938/jsn.v $\underline{12 \mathrm{i} 1.340}$

\section{ABSTRAK \\ Efektivitas Tablet Klorin Dalam Menurunkan Kandungan Coliform Pada Instalasi Pengolahan Air Limbah}

Air limbah yang berasumber dari kandang hewan coba yang tidak diolah dengan tepat dapat menjadi sumber pencemaran karena mengandung bahan organik, anorganik bahkan mikroorganisme pathogen. Desinfeksi meggunakan klorin merupakan tahapan terakhir pada proses pengolahan air limbah untuk mengurangi mikroorganisme. Tujuan dari penelitian ini adalah mengetahui efektivitas tablet klorin dalam menurunkan kandungan Coliform dari air limbah kandang hewan coba di Instalasi Pengolahan Air Limbah (IPAL) agar memenuhi baku mutu Total Coliform dalam Peraturan Menteri Lingkungan Hidup dan Kehutanan No. 68 Tahun 2016 tentang baku mutu air limbah domestik. Penelitian dilakukan dengan menggunakan eksperimen laoboratorium pre dan post test. Sampel air limbah diambil dari 2 titik yaitu titik inlet (sebelum pengolahan) dan outlet (sesudah klorinasi), uji MPN Coliform (SNI 2897 2008) dilakukan dua kali ulangan, serta mengukur pH dan suhu untuk menganalisis faktor lingkungan. Hasil penelitian menunjukkan tablet klorin sebanyak $200 \mathrm{~g}$ efektif dapat menurunkan Coliform hingga 98,55 \% dan memenuhi baku mutu yang dijadikan acuan.

Kata Kunci: Coliform, Klorin, air limbah, IPAL dan baku mutu.

\section{PENDAHULUAN}

Air limbah merupakan pencemar terbesar yang masuk ke wilayah perairan, dan jika langsung di buang ke lingkungan tanpa pengolahan akan meningkatkan pencemaran (Susanthi et al., 2018). Hal ini terjadi karena komposisi air limbah rata-rata yang mengandung senyawa organik dan senyawa mineral berbentuk suspensi atau bahan terlarut bahkan organisme pathogen sehingga berpotensi untuk menjadi sumber pencemaran (Astika et al., 2017). Bakteri Coliform merupakan bakteri yang dapat ditemukan pada air limbah yang bersumber dari 
kandang hewan coba karena bercampurnya air sisa pencucian kandang dengan feses hewan. Oleh karena itu, perlu dilakukan pengolahan pada Instalasi Pengolahan Air Limbah (IPAL) sebelum dibuang ke lingkungan (Widyastuti et al., 2013).

\section{Bakteri Coliform merupakan} mikroorganisme indikator yang menentukan kualitas sumber air yang tercemar (Pakpahan et al., 2015). Bakteri Coliform adalah bakteri berbentuk batang, gram negatif, mampu memfermentasi laktosa serta membentuk asam dan gas pada suhu $37{ }^{\circ} \mathrm{C}$. Contoh bakteri Coliform antara lain Escherichia coli, Klebsiella sp. dan Enterobacter sp. (Wiliantari et al., 2018). Total Coliform digunakan sebagai parameter standar mutu mikrobiologi karena keberadaannya berkorelasi positif dengan keberadaan mikroorganisme pathogen. Untuk mengurangi atau bahkan membunuh mikroorganisme dalam air limbah, digunakan desinfektan untuk meningkatkan kualitas bakteriologisnya sehingga jumlah mikroorganisme yang terkandung didalamnya berkurang (Agung et al., 2009). Klorin merupakan desinfektan yang umum digunakan pada proses pengolahan air, karena ekonomis dan mudah didapat, namun penggunaan klorin yang berlebih akan menimbulkan efek klinis (Widyaningsih et al., 2016). Efektivitas dari penggunaan klorin perlu diketahui sehingga bahaya yang ditimbulkan dapat diminimalisir (Agung, 2009).

Instansi ' $\mathrm{X}$ ' memiliki fasilitas IPAL System Contact Aeration atau Submerged Fixed Film Bioreactor (ASFF) untuk mengolah air limbah dengan volume harian $49 \mathrm{~m}^{3}$ bersumber dari kandang hewan percobaan dan wastafel bangunan utama. Desinfektan yang digunakan pada bak klorinasi di IPAL tersebut adalah tablet klorin $200 \mathrm{~g}$ berkadar 90\%. Berdasarkan penelitian pendahuluan, pada penggunaan tablet klorin sebanyak $400 \mathrm{~g}$ diperoleh nilai penurunan Coliform dari $>1,1 \times 10^{5} \mathrm{sel} / 100 \mathrm{~mL}$ menjadi 0 sel/100 $\mathrm{mL}$, sehingga dijadikan dasar untuk menurunkan massa klorin dalam memenuhi baku mutu yang dijadikan acuan.

Supriyadi (2010) menyatakan bahwa dosis optimum klorin untuk menurunkan kandungan bakteri Coliform total dan Escherichia coli pada sampel air sungai Garang, sungai Kreo dan sungai Tugu Soeharto sebesar 3,5 mg/L dengan efisiensi tercapai $100 \%$ pada dosis $4 \mathrm{mg} / \mathrm{L}$ (Supriyadi. et al., 2010). Hasil penelitian lain menunjukkan bahwa penggunaan klorin dari limbah domestik pada bak clarifier (ember penjernih air), menghasilkan kualitas air dengan parameter E. coli sebesar $0 \mathrm{MPN} / 100 \mathrm{~mL}$ pada penambahan dosis $350 \mathrm{mg} / \mathrm{L}$ dan $400 \mathrm{mg} / \mathrm{L}$ (Ratnawati \& Sugito, 2013). Berdasarkan latar belakang di atas, maka perlu dianalisis jumlah tablet klorin yang efektif dalam memenuhi Total Coliform yang diperkenankan berdasarkan baku mutu Peraturan Menteri Lingkungan Hidup dan Kehutanan No. 68 Tahun 2016 Tentang Baku Mutu Air Limbah Domestik dimana batas maksimum Coliform sebesar 3000 (Kementerian Lingkungan Hidup dan Kehutanan, 2016).

\section{BAHAN DAN METODE}

\section{Bahan dan Alat}

Bahan yang digunakan dalam penelitian ini adalah sampel air limbah yang bersumber dari kandang hewan percobaan dan lavatory dengan debit harian $40 \mathrm{~m}^{3}$ dengan kadar BOD $200 \mathrm{mg} / \mathrm{L}$ serta dari wastafel bangunan utama sebanyak 9 $\mathrm{m}^{3}$ dengan BOD maksimum $50 \mathrm{mg} / \mathrm{L}$. Selanjutnya bahan-bahan lain yang digunakan adalah media Buffered Pepton Water (BPW) merk Himedia ${ }^{\mathrm{TM}}$, media Lauryl Tryptose Broth (LSTB) merk Oxoid ${ }^{\mathrm{TM}}$, media Brilliant Green Bile Broth (BGLB) merk Oxoid ${ }^{\mathrm{TM}}$ dan air demineralisasi hasil produksi mesin Organo ${ }^{\mathrm{TM}}$.

Alat-alat yang digunakan dalam penelitian ini adalah timbangan elektrik Shimadzu Libror EB 3300 HW, pH meter merk Horiba Laqua F74 $\mathrm{BW}, \mathrm{pH}$ meter portable, thermometer air raksa, autoclave Hirayama, Biosafety Cabinet Level 2 ESCO Labculture, incubator Memmert, magnetic stirrer merk Iuchi, vortex mixer merk Biosan, automatic pippete jet merk Eppendorf, ose sterilizer merk Etna Glowzone, rak tabung, botol Durran, gelas ukur, pipet volumetrik, kertas timbang, sendok takar, labu Erlenmeyer, tabung reaksi, tabung Durham, Petri disc, dan alat pelindung diri.

\section{Metode}

Jenis penelitian berbasis eksperimen dengan metode pre dan post test. Sampel yang digunakan adalah air limbah kandang hewan coba dari 2 (dua) titik yaitu titik inlet (sebelum pengolahan di IPAL) dan outlet (telah mendapatkan perlakuaan klorinasi di IPAL) dengan penambahan variasi tablet klorin sebanyak 100, 200, 300 dan 400 g. Metode yang digunakan mengacu pada SNI 2897:2008 tentang 
uji Most Probable Number (MPN) Coliform menggunakan 2 tahapan pengujian yakni uji pendugaan (presumptive test) dan uji penegasan (confirmed test) (BSN, 2008). Langkah-langkah yang dilakukan dalam penelitian ini yakni:

\section{Aplikasi Tablet Klorin Pada Bak Klorinasi di IPAL dengan variasi 100, 200, 300 dan $400 \mathrm{~g}$.} Aplikasi tablet klorin pada IPAL dilakukan dengan cara membuka tutup bak klorinasi kemudian menambahkan tablet klorin dengan variasi 100, 200, 300, dan 400 g. Pada masing-masing aplikasi tablet klorin diberikan waktu jeda untuk meminimalisir sisa efek aplikasi tablet klorin sebelumnya.

\section{Pengambilan Sampel Air Limbah}

Sampel air diambil dari titik inlet dan outlet IPAL menggunakan botol durran steril sebanyak masing-masing $100 \mathrm{~mL}$. Setiap sampel dari bak inlet dan bak outlet diambil masingmasing 2 botol. Kemudian sampel air limbah di bawa ke laboratorium untuk dilakukan pengujian Coliform. Sampel yang akan diuji tidak boleh lebih dari 24 jam setelah pengambilan. Pada masing-masing sampel dilakukan pengukuran $\mathrm{pH}$ dan suhu secara duplo untuk mengetahui faktor lingkungan.

\section{Pengujian MPN Coliform}

Pengujian dilakukan menggunakan metode MPN dengan 2 (dua) tahapan pengujian meliputi uji praduga dan uji penegasan pada media spesifik. Uji MPN pada penelitian ini menggunakan ragam 333 (9 tabung) yang merupakan ragam alternatif dalam uji MPN.

Pada tahapan uji praduga dilakukan pengenceran menggunakan media Buffered Pepton Water (BPW) hingga diperoleh pengenceran $10^{-1}, 10^{-2}$, dan $10^{-3}$. Selanjutnya dari masing-masing pengenceran tersebut didistribusikan masing-masing sebanyak $1 \mathrm{~mL}$ ke dalam 3 tabung media Lauryl Sulphate Broth (LSTB) $9 \mathrm{~mL}$ dan diinkubasikan selama 24-48 jam dan diamati adanya gas pada tabung durham. Jika pada uji praduga positif maka dilakukan uji konfirmasi, dan jika hasil uji praduga negatif maka pengujian dikatakan selesai (Amelia, 2019; Suriaman \& Apriliasari 2017).

Pada uji konfirmasi dari masing-masing tabung yang diduga positif Coliform diambil sebanyak 1 (satu) ose untuk selanjutnya diinokulasikan ke dalam media BGLB dan diinkubasikan pada suhu $37^{\circ} \mathrm{C}$ selama $24-48$ jam untuk melihat adanya gas pada tabung durham.
Hal ini memperkuat keberadaan Coliform pada sampel air. Hasil uji MPN kemudian dikonfirmasi ke dalam tabel MPN seri 3 (tiga) tabung dalam Bacteriological Analitycal Manual Edisi 8.

Hasil positif pada uji praduga ditandai dengan adanya gas pada tabung durham (10\% atau lebih dari volume tabung durham) serta perubahan warna media LSTB dari kuning bening ke kuning keruh. Hal ini disebabkan karena bakteri Coliform memfermentasi laktosa yang terdapat dalam media cair LSTB yang menghasilkan asam piruvat dan asam asetat sehingga muncul gelembung gas $\mathrm{CO}_{2}$ yang terperangkap dalam tabung durham yang terbalik (Putri \& Kurnia, 2018). Sedangkan hasil negatif ditandai dengan tidak terbentuknya gelembung gas pada tabung durham. Hasil pada uji praduga ini memiliki probabilitas rendah, sehingga pengujian dilanjutkan ke uji konfirmasi pada media BGLB (Jiwintarum et al., 2017). Media BGLB dapat menghambat pertumbuhan bakteri gram positif sehingga hanya bakteri Coliform saja yang dapat tumbuh. Media ini mengandung laktosa dan garam empedu sehingga Coliform dapat tumbuh secara optimal.

\section{Analisis Data}

Jumlah Coliform yang diperoleh dari tabel MPN seri 3 (tiga) tabung kemudian dihitung menggunakan rumus di bawah ini (Kartikasari et al., 2019).

Jumlah Koloni/100 $\mathrm{mL}=$ Nilai $M P N$ tabel $x \frac{1}{\text { Pengenceran di tengah }}$

\section{HASIL DAN PEMBAHASAN}

\section{Nilai Most Probable Number (MPN) Air Limbah}

Metode Most Probable Number (MPN) merupakan metode uji kualitas air atau bahan pangan olahan untuk menghitung jumlah perkiraan mikroorganisme terdekat pada sampel uji dengan menggunakan medium cair tertentu. Hasil positif pada uji ini ditandai dengan adanya gas sebanyak $10 \%$ atau lebih dari volume tabung durham yang disimpan terbalik dalam tabung reaksi. Metode MPN merupakan metode yang paling sensitif untuk mendeteksi keberadaan Coliform dalam batas yang rendah (Aminah \& Wahyuni, 2018). Nilai MPN Coliform sebelum dan sesudah klorinasi dapat dilihat pada Gambar 1. 


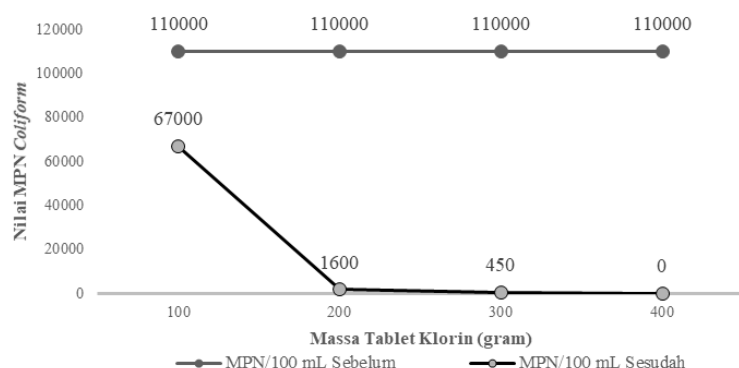

Gambar 1. Nilai MPN Coliform sebelum dan sesudah klorinasi

Berdasarkan hasil pada Gambar 1, sampel air limbah pada inlet di IPAL memiliki nilai MPN > $110000 \mathrm{sel} / 100 \mathrm{~mL}\left(>1,1 \times 10^{5}\right)$, sehingga tidak memenuhi baku mutu yang dipersyaratkan yaitu $3000 \mathrm{sel} / 100 \mathrm{~mL}$. Nilai MPN Coliform air limbah yang tinggi di Instansi ' $X$ ' disebabkan oleh sumber air limbah yang bercampur dengan air pencucian dan belum mengalami serangkaian pengolahan pada IPAL, sehingga untuk meningkatkan mutu secara bakteriologis perlu dilakukan pengolahan sebelum dibuang ke lingkungan atau badan air (Sulistiyawati, 2019). Sementara itu, setelah diberikan tablet klorin dengan variasi 100, 200, 300 dan $400 \mathrm{~g}$, nilai MPN Coliform mengalami penurunan. Pada penambahan $100 \mathrm{~g}$ tablet klorin, nilai MPN turun dari $>110000 \mathrm{sel} / 100 \mathrm{~mL}$ menjadi $67000 \mathrm{sel} / 100$ $\mathrm{mL}$. Sedangkan, pada penambahan tablet klorin 200 g, nilai MPN Coliform turun menjadi 1600 $\mathrm{sel} / 100 \mathrm{~mL}$. Pada penambahan $300 \mathrm{~g}$ tablet klorin, nilai MPN Coliform turun menjadi 450 sel/100 mL, sedangkan pada penambahan $400 \mathrm{~g}$ tablet klorin, nilai MPN turun menjadi 0 sel/100 $\mathrm{mL}$. Berdasarkan hasil di atas dapat terlihat bahwa semakin tinggi massa klorin yang diberikan pada bak klorinasi IPAL, maka semakin tinggi penurunan jumlah MPN Coliform. Untuk memenuhi baku mutu yang digunakan yakni nilai MPN Coliform 3000 sel/100 mL, maka penambahan tablet klorin 200 $\mathrm{g}$ adalah yang paling efektif dengan nilai MPN $1600 \mathrm{sel} / 100 \mathrm{~mL}$. Penambahan tablet klorin pada bak klorinasi dapat mengurangi Coliform hingga $100 \%$ terlihat pada penambahan tablet klorin sebanyak $400 \mathrm{~g}$.

\section{Derajat Keasaman (pH)}

Derajat keasaman (pH) rata-rata meningkat setelah klorinasi pada IPAL (Gambar 2). Perubahan $\mathrm{pH}$ yang cenderung basa disebabkan oleh penambahan klorin, semakin banyak klorin yang ditambahkan maka $\mathrm{pH}$ air meningkat (Sawyer, 2003). Reaksi yang terjadi dapat dilihat seperti berikut ini:

$$
\begin{aligned}
2 \mathrm{Ca}(\mathrm{OCl})_{2(\mathrm{~s})}+ & 2 \mathrm{H}_{2} \mathrm{O}{ }_{(\mathrm{l})} \rightarrow \\
& 2 \mathrm{CaO}_{(\mathrm{s})}+2 \mathrm{HOCl}_{(\mathrm{aq})}+2 \mathrm{HCl}_{(\mathrm{aq})}+\mathrm{O}_{2(\mathrm{~g})} \uparrow \\
\mathrm{Ca}(\mathrm{OH})_{2(\mathrm{~s})} \rightarrow & \mathrm{Ca}^{2+}{ }_{(\mathrm{aq})}+\mathrm{OH}^{-}{ }_{(\mathrm{aq})}
\end{aligned}
$$

Klorin di dalam air akan terhidrolisis dan membentuk senyawa $\mathrm{Ca}(\mathrm{OH})_{2}$ (basa kuat) dan $\mathrm{HOCl}$ (basa lemah), kemudian senyawa $\mathrm{Ca}(\mathrm{OH})_{2}$ akan terurai membentuk ion $\mathrm{Ca}^{2+}$ dan ion $\mathrm{OH}^{-}$yang mengakibatkan larutan bersifat basa. Hal ini disebabkan oleh keberadaan ion $\mathrm{OH}^{-}$ yang lebih besar dibandingkan ion $\mathrm{H}^{+}$(Sawyer, 2003). Pada penelitian ini, $\mathrm{pH}$ air limbah berada dalam rentang 6-9, sehingga masih memenuhi baku mutu yang dipersyaratkan. Klorin efektif mendisinfeksi air yang memiliki $\mathrm{pH}$ netral, jika $\mathrm{pH}$ melebihi 8,5 asam hipoklorit akan terionisasi menjadi hipoklorit sehingga mengurangi efektivitas klorin sebagai desinfektan (Suri, 2019). pH merupakan kontrol dari klorinasi, pH yang terlalu rendah bersifat korosif, sehingga mengakibatkan korosi, sedangkan $\mathrm{pH}$ yang terlalu tinggi bersifat kaustik.

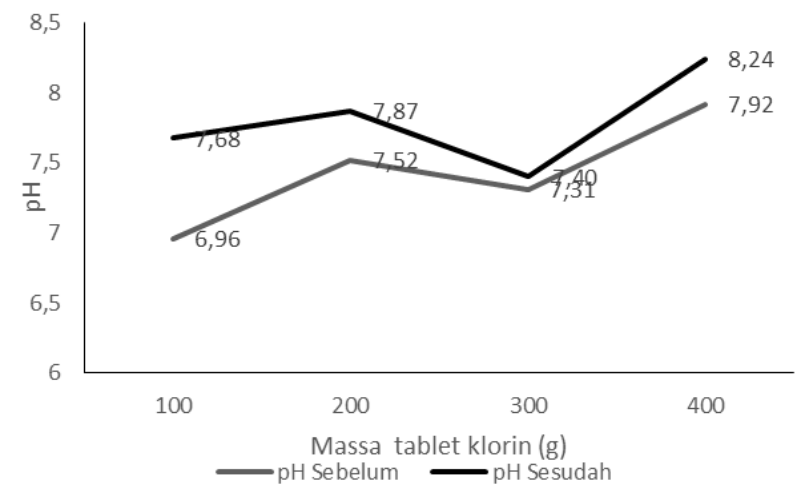

Gambar 2. Pengukuran pH air limbah sebelum dan sesudah klorinasi

\section{Suhu}

Suhu rata-rata air limbah setelah klorinasi meningkat (Gambar 3), hal ini dapat disebabkan oleh adanya udara yang masuk ke bak klorinasi saat tutupnya dibuka, adanya pengaruh dari suhu lingkungan saat pengambilan sampel air. Peningkatan suhu juga dapat disebabkan oleh aktivitas desinfeksi dari tablet klorin yang digunakan, karena semakin efektif proses klorinasi, maka suhu akan naik yang akan mempercepat proses desinfeksi air limbah (Nugrayanti et al., 2018). Pada penambahan tablet klorin 300 gram suhu mengalami penurunan hal ini disebabkan oleh factor lingkungan saat oengambilan sampel. Menurut 
Kerubun (2014) suhu air limbah terklorinasi lebih tinggi dari suhu sebelum pengolahan, hal ini disebabkan penggunaan bahan kimia organik maupun anorganik (Kerubun, 2014). Hasil pengukuran suhu air limbah sebelum dan sesudah klorinasi masih memenuhi baku mutu yaitu kurang dari dari $\quad 30 \quad{ }^{\circ} \mathrm{C}$ sebagaimana dipersyaratkan dalam Keputusan Menteri Negara Lingkungan Hidup Nomor Kep51/MenLH/10/1995 yakni maksimal $30{ }^{\circ} \mathrm{C}$.

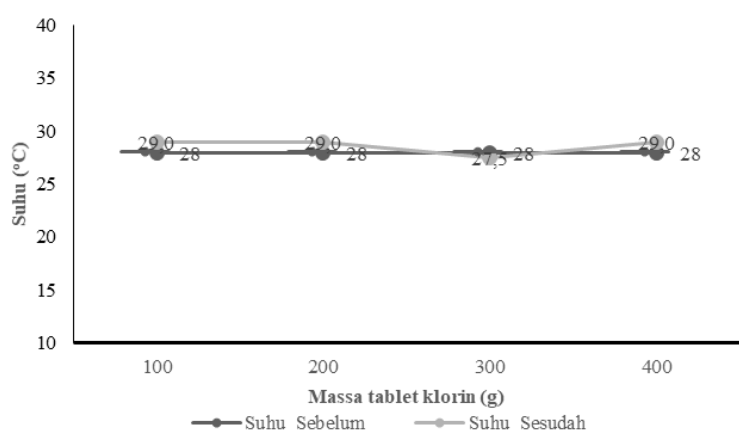

Gambar 3. Pengukuran suhu air limbah sebelum dan etelah klorinasi

\section{Nilai Efektiviatas Tablet Klorin Dalam Menurunkan Coliform}

Nilai MPN yang diperoleh berdasarkan uji MPN Coliform, kemudian dihitung untuk memperoleh presentase efektifitas dari penggunaan tablet klorin terhadap penurunan Coliform air limbah. Selanjutnya, hasil tersebut dibandingkan dengan batas maksimal nilai MPN Coliform pada baku mutu yang dijadikan acuan. Nilai efektivitas tablet klorin terhadap penurunan kandungan Coliform dapat dilihat pada Gambar 4.

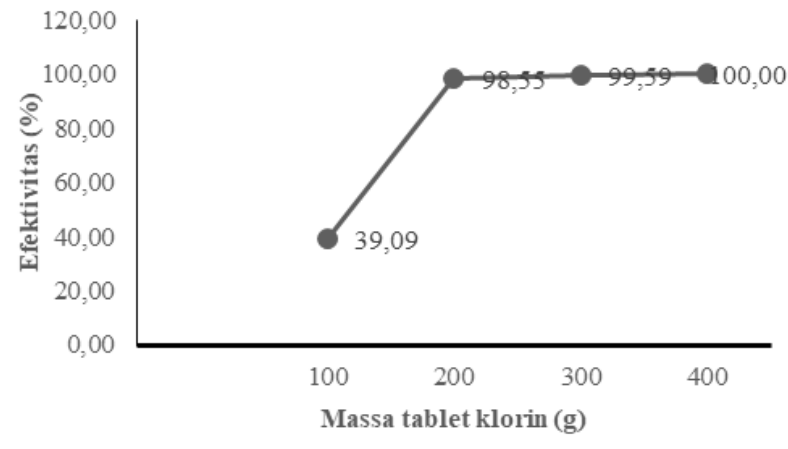

Gambar 4. Nilai efektivitas tablet klorin dalam menurunkan Coliform

Tablet klorin $400 \mathrm{~g}$ memiliki daya bunuh paling efektif (100\%) (Gambar 4) dengan nilai
MPN 0 sel/100 mL (Gambar 1.). Sedangkan tablet klorin yang paling efektif dalam memenuhi baku mutu Peraturan Menteri Lingkungan Hidup dan Kehutanan No. 68 Tahun 2016 adalah tablet klorin $200 \mathrm{~g}$ dengan nilai MPN $1600 \mathrm{sel} / 100 \mathrm{ml}(98,55 \%)$. Penggunaan klorin dalam bak klorinasi merupakan cara yang efektif untuk mengurangi kontaminasi Coliform karena khasiatnya sebagai desinfektan mampu merusak sel bakteri, merusak asam nukleat dan enzim (Busyairi et al., 2016).

Selain berperan sebagai desinfektan, klorin juga dapat memberikan dampak negatif bagi lingkungan yaitu menjadi limbah sehingga tablet klorin 400 gram bukan pilihan yang tepat dalam menurunkan kandungan Coliform air limbah kandang hewan coba di Instansi ' $\mathrm{X}$ ', karena tablet klorin 200 gram efektif $98.55 \%$ menurunkan Coliform dalam memenuhi baku mutu yang dijadikan acuan. Limbah cair yang mengandung klorin dapat mencemari perairan dan ekosistem di dalamnya. Besarnya pengaruh tergantung pada tingkat dan jenis senyawa serta tingkat toksisitasnya. Klorin menghasilkan senyawa organoklorin seperti Polychlorinated Bipheniyls (PCBs), dioksin, Dichloro Dietil Trichloromethana (DDT) dan lain-lain yang dapat mengganggu kekebalan, merusak hati dan ginjal, gangguan pencernaan, gangguan sistem saraf, gangguan sistem reproduksi bahkan kanker (Hasan, 2006). Oleh karena itu, penggunaan klorin yang efektif bertujuan untuk mengendalikan atau mengurangi residu klorin yaitu senyawa halogen organik dan trihalometana (THM) (Busyairi et al., 2016).

\section{KESIMPULAN}

MPN Coliform pada titik inlet IPAL yaitu sebesar >110000 sel/100 mL (>1,1 x $\left.10^{5}\right)$ sehingga tidak memenuhi baku mutu yang dipersyaratkan yaitu $3000 \mathrm{sel} / 100 \mathrm{~mL}$. Nilai MPN Coliform air limbah pada titik inlet yang tinggi disebabkan oleh sumber air limbah kandang hewan coba yang bercampur dengan air pencucian dan belum mengalami serangkaian pengolahan pada IPAL, sehingga untuk meningkatkan mutu air limbah secara bakteriologis, perlu dilakukan pengolahan terlebih dahulu sebelum di buang ke lingkungan atau badan air.

Penambahan tablet klorin dengan variasi 100, 200, 300 dan $400 \mathrm{~g}$ pada bak klorinasi di IPAL dapat mengurangi Total Coliform pada air 
limbah yang bersumber dari kandang hewan coba di Instansi ' $\mathrm{X}$ ' dengan efektifitas $100 \%$ pada tablet klorin $400 \mathrm{~g}$ dengan jumlah Coliform diperoleh 0 sel/100 mL. Sedangkan untuk memenuhi baku mutu yang ditetapkan dalam Peraturan Menteri Lingkungan Hidup dan Kehutanan No.68 Tahun 2016 adalah tablet klorin $200 \mathrm{~g}$ dengan efektivitas $98.55 \%$ yakni Total Coliform diperoleh $1,6 \times 10^{3} \mathrm{sel} / 100 \mathrm{~mL}$.

\section{UCAPAN TERIMA KASIH}

Penulis mengucapkan terima kasih kepada Balai Besar Pengujian Mutu dan Sertifikasi Obat Hewan, Gunungsindur Kabupaten Bogor, atas izin yang diberikan untuk dilakukan penelitian pada Instalasi Pengolahan Air Limbah. Selain itu penulis mengucapkan terima kasih pada laboran di Unit Uji Bakteriologi dan Supply Centre.

\section{DAFTAR PUSTAKA}

Agung, T. U. (2009). Analisis Kadar Khlorida Pada Air Dan Air Limbah Dengan Metode Argentometri. Karya Tulis Ilmiah. Universitas Sumatera Utara. Medan.

Amelia, F. (2019). Identifikasi Bakteri Coliform Pada Air Minum Dalam Kemasan (AMDK) Yang Diproduksi Di Kota Batam. Simbiosa, 8(1), 85. https://doi.org/10.33373/simbio.v8i1.1907

Aminah, S., \& Wahyuni, S. (2018). Hubungan Konstruksi Sumur Dan Jarak Sumber Pencemaran Terhadap Total Coliform Air Sumur Gali Di Dusun 3A Desa Karang Anyar Kecamatan Jati Agung Kabupaten Lampung Selatan Relationship Construction Well And Distance Source Pollution Against Total Coliform W. Jurnal Analisis Kesehatan, 7(1), 1-6. ejurnal.poltekkestjk.ac.id/index.php/JANALISKES/articl e/view/921

Astika, A. U. W., Sudarno, S., \& Zaman, B. (2017). Kajian Kinerja Bak Settler, Anaerobic Baffled Reactor (Abr), Dan Anaerobic Filter (Af) Pada Tiga Tipe Ipal Di Semarang. Jurnal Teknik Lingkungan, 6(1), 1-15.
Busyairi, M., Dewi, Y. P., \& Widodo, D. I. (2016). Efektivitas Kaporit Pada Proses Klorinasi Terhadap Penurunan Bakteri Coliform Dari Limbah Cair Rumah Sakit $\mathrm{X}$ Samarinda (The Effectiveness of Calcium Hypochlorite to Chlorination Process in Decreasing the Amount of Coliform Bacteria in the Wastewater of X). Jurnal Manusia Dan Lingkungan, 23(2), 156. https://doi.org/10.22146/jml.18786

Hasan, A. (2006). Dampak penggunaan klorin. $J$. Tek. Lingk. P3TL-BPPT, 7(1), 90-96. http://ejurnal.bppt.go.id/ejurnal2011/ind ex.php/JTL/article/view/456/472

Badan Standardisasi Nasional [BSN]. (2008). Metode pengujian cemaran mikroba dalam daging, telur dan susu, serta hasil olahannya.BSN.

Jiwintarum, Y., Agrijanti, \& Septiana, B. L. (2017). Most Probable Number (Mpn) Coliform Dengan Variasi Volume Media Lactose Broth Single Strength (Lbss) Dan Lactose Broth Double Strength (Lbds). Jurnal Kesehatan Prima, 11(1), 1.

Kartikasari, A. M., Hamid, I. S., Purnama, M. T. E., Damayanti, R., Fikri, F., \& Praja, R. N. (2019). Isolasi dan Identifikasi Bakteri Escherichia coli Kontaminan Pada Daging Ayam Broiler Di Rumah Potong Ayam Kabupaten Lamongan. Jurnal Medik Veteriner, 2(1), 66. https://doi.org/10.20473/jmv.vol2.iss1.2 019.66-71

Kementerian Lingkungan Hidup dan Kehutanan. (2016). Peraturan Menteri LHK No.68 th 2016 tentang Baku Mutu Air Limbah Domestik. Kementerian Lingkungan Hidup Dan Kehutanan, 68, 1-13. http://neo.kemenperin.go.id/files/hukum /19 Permen LHK th 2016 No. P.63 Baku Mutu Air Limbah Domestik.pdf

Kerubun, A. A. (2014). Wastewater Quality in Tulehu Regional Public Hospital Ali. Media Kesehatan Masyarakat Indonesia, 180-185.

Nugrayanti, M. S., Dermawan, D., \& Dewi, T. U. (2018). Pengaruh pemberian dosis trichloroisocyanuric acid (tcca) pada bak desinfeksi terhadap penurunan 
kandungan escherichia coli di RSUD Dr. R. Koesma Tuban. Conference Proceeding on Waste Treatment Technology, 1(1), 129-134.

Pakpahan, R. S., Picauly, I., \& Mahayasa, I. N. W. (2015). Cemaran Mikroba Escherichia coli dan Total Bakteri Koliform pada Air Minum Isi Ulang. Kesmas: National Public Health Journal, $\quad 9(4), \quad 300$. https://doi.org/10.21109/kesmas.v9i4.7 33

Putri, A. M., \& Kurnia, P. (2018). Identifikasi Keberadaan Bakteri Coliform Dan Total Mikroba Dalam Es Dung-Dung Di Sekitar Kampus Universitas Muhammadiyah Surakarta. Media Gizi Indonesia, $13(1), \quad 41$. https://doi.org/10.20473/mgi.v13i1.4148

Ratnawati, R., \& Sugito. (2013). Proses Desinfeksi Pada Pengolahan Air Limbah Domestik Menjadi Air Bersih Sebagai Air Baku Air Minum. Jurnal Teknik, 11(2), 2-4.

Sawyer, C. N. (2003). Chemistry For Enviromental Engineering and Science. McGraw-Hill.

Sulistiyawati, I. (2019). Kuantitas Total Bakteri Coliform pada Instalasi Pengolahan Limbah Cair Medis Laboratorium Klinik. Jurnal Ilmiah Universitas Batanghari Jambi, 19(3), 675. https://doi.org/10.33087/jiubj.v19i3.718

Supriyadi., Sumantri, I., \& Hartati., I. (2010). Pengaruh Dosis Klorin Pada Pertumbuhan Bakteri Coliform Total Dan Escherichia Coli Pada Sungai Kreo, Sungai Garang Dan Sungai Tugu Suharto. Banlit Fakultas Teknik Universitas Wahid Hasyim Semarang, 12(1), 30-35.
Suriaman, E., \& Apriliasari, W. P. (2017). Uji Mpn Coliform Dan Identifikasi Fungi Patogen Pada Air Kolam Renang Di Kota Malang. Jurnal SainHealth, 1(1), 15. https://doi.org/10.51804/jsh.v1i1.73.1522

Susanthi, D., Purwanto, M. Y., \& Suprihatin, S. (2018). Evaluasi Pengolahan Air Limbah Domestik dengan IPAL Komunal di Kota Bogor. Jurnal Teknologi Lingkungan, 19(2), 229. https://doi.org/10.29122/jtl.v19i2.2834

Widyaningsih, W., Supriharyono, S., \& Widyorini, N. (2016). Analisis Total Bakteri Coliform Di Perairan Muara Kali Wiso Jepara. Management of Aquatic Resources Journal (MAQUARES), 5(3), 157-164. https://doi.org/10.14710/marj.v5i3.1440 3

Widyastuti, F. R., Purwanto, \& Hadiyanto. (2013). Upaya pengelolaan lingkungan usaha peternakan sapi di Kawasan Usahatani Terpadu Bangka Botanical Garden Pangkalpinang. Prosiding Seminar Nasional Pengelolaan Sumber Daya Alam Dan Lingkungan Dalam Mewujudkan Pembangunan Berkelanjutan, 237, 81-85. http://www.psil.undip.ac.id

Wiliantari, P., Besung, I. N. K., \& Tono PG, K. (2018). Bakteri Coliform dan Non Coliform yang Diisolasi dari Saluran Pernapasan Sapi Bali. Buletin Veteriner Udayana, $\quad$ 10(1), 40. https://doi.org/10.24843/bulvet.2018.v1 0.i01.p06

Suri, P.M. (2019). Analisa Kadar Klorin Pada Air Kolam Renang Deli di Kota Medan. Karya Tulis Ilmiah. Politeknik Kesehatan Kemenkes. Medan. 87(1,2), 149-200. 